\title{
Rice growth and yield under twenty years of cropping in a long term fertilizer experiment in central laterites of Kerala
}

V. Thulasi, P. P. Moossa and Muneswar Singh

Received : 10.04.2020; Revised : 07.05.2020; Accepted : 25.05.2020

MEMBERS OF RESEARCH FORUM:

Corresponding author : V. Thulasi, Regional Agricultural Research Station, Pattambi (Kerala) India

Email: thulasi.v@kau.in

Co-authors :

P.P. Moossa, Regional Agricultural Research Station, Pattambi

(Kerala) India

Muneswar Singh, Indian Institute of Soil Science, Bhopal (M.P.) India

\begin{abstract}
Summary
The AICRP on long term fertilizer experiment was established at RARS Pattambi in 1997 and the experiment is being conducted continuously in the same field. The objective of the experiment was to study the effect of long term application of fertilizers and manures on growth and yield of the plant and monitoring of soil quality. The experiment consists of 12 treatments. The LTFE experiment with 20 years cropping history revealed the superiority of integrated nutrient management with 100 per cent NPK along with FYM over the sole use of fertilizers. However in situ growing of dhaincha (Sesbania aculeata) also offer a good solution for integration of manures and fertilizers. Integrated nutrient management and in situ green manuring with daincha recorded higher grain and straw yield and the growth parameters corroborated the trends in yield.
\end{abstract}

Key words : LTFE, Laterite soil, INM, Long term fertilizer experiments

How to cite this article : Thulasi, V., Moossa, P.P. and Singh, Muneswar (2020). Rice growth and yield under twenty years of cropping in a long term fertilizer experiment in central laterites of Kerala. Asian J. Soil Sci., 15(1): 41-45 : DOI : 10.15740/HAS/AJSS/15.1/41-45.Copyright@ 2020: Hind Agri-Horticultural Society. 